Article

\title{
Fuel Consumption Test Results for a Self-Adaptive, Maintenance-Free Wood Chipper Drive Control System
}

\author{
Łukasz Warguła *(D), Piotr Krawiec, Konrad Jan Waluś and Mateusz Kukla \\ Department of Mechanical Engineering, Poznan University of Technology, 60-965 Poznan, Poland; \\ piotr.krawiec@put.poznan.pl (P.K.); konrad.walus@put.poznan.pl (K.J.W.); mateusz.kukla@put.poznan.pl (M.K.) \\ * Correspondence: lukasz.wargula@put.poznan.pl; Tel.: +48-(61)-665-20-42
}

Received: 16 March 2020; Accepted: 10 April 2020; Published: 15 April 2020

check for updates

\begin{abstract}
Both energy consumption and the ecology of mobile wood-chipping machines are important issues in forest management. One way of improving the efficiency of wood-chippers is to use innovative design solutions in drive unit control systems. This can result in a reduction in fuel consumption and quantitative exhaust gas emissions. This article presented the results of research conducted on the fuel consumption of a cylindrical wood chipper driven by a small engine. We carried out testing of the unmodified chipper (A), made two different chipper modifications (B) and (C), and tested the modified versions to achieve the indicated results. The process allowed analysis and comparison of recorded data. For this purpose, the engine was supplied with fuel in three different ways: carburetor (factory-made) (A), the injector (B), and injector with an adaptative drive control system (designed by the authors) (C). The construction of a maintenance-free and adaptive drive control system where its functioning depended on operating conditions was done following patent application P.423369. All three fuel supply systems: A, B, and C were tested experimentally in terms of fuel consumption. The research was conducted in both set exploitation conditions (idle work with high (1) and low (2) rotational speed, with a continuous chipping process (3)) and transient exploitation conditions (4) (resulting from the delivery time of wood waste). Thus, the first stage of research involved two constructions $(\mathrm{A}, \mathrm{B})$ for three different working conditions (1-3). The second stage consisted of three constructions (A-C) tested in the fourth working conditions (4). The tests showed that the injection system reduced fuel consumption by around $61 \%$ during the continuous chipping process in comparison with the carburetor system. The adaptive drive control system (C) reduced fuel consumption by $55-74 \%$ in comparison with the carburetor system (A), and by $24-60 \%$ in comparison with the injection system (B) without an adaptive drive control system. The level of energy consumption in these systems depended directly on the ratio of idle work time during the chipping process.
\end{abstract}

Keywords: adaptive drive system; reduction of fuel consumption; wood chipper

\section{Introduction}

The introduced innovations in machines for forestry are based on pro-ecological solutions and solutions that bring growth to the economy of the related technological processes. These processes are wood transportation [1], biomass transportation [2], tree felling [3], and transportation [4,5], including used collection systems [6]. One of the essential machines used in the process of pruning and cutting trees regardless of their purpose and place of service (for example forests, orchards, urbanized, and roadside areas) are wood chippers.

The available literature on the energy consumption of wood waste transformation processes in forests [7] shows that the methods currently employed for collecting, chipping, and transporting 
forest biomass in the form of chips are very efficient from the energy balance point of view [2]. The development of these machines is focused mainly on the development of their working mechanisms [8] and the machine's settings and configuration [9].

Significant progress has been made in the collection of raw wood materials owing to the introduction of modern harvesters, forwarders, and tower yarders. However, there are certain forest areas where the use of these machines is either difficult or impossible [10]. In such cases, mobile chipping machines equipped with small engines are used. These devices affect the natural environment (locally and globally), as well as the people who operate them [11]. The internal combustion engines powering these machines also consume non-renewable energy sources and emit harmful exhaust gases and noise [12-17]. Permissive regulations regarding exhaust gas emissions [18] have resulted in the low technical sophistication of these types of drive units [19].

The scientific development trends are to use drive units with electronic fuel injection [20], to use engines that run on alternative fuels [21], and to use drive units that adapt to operating conditions [22,23]. These trends are technologically ahead of the designs that meet the European emission regulations introduced in 2019 (Regulation (EU) No 2016/1628) [24].

In the wood waste chipping process, the exploitation conditions are irregular (thus exploitation conditions are considered as transient) but can be estimated successfully with certain periodicallyvariable conditions. This result is due to the frequency of waste (branches) supply to the working unit of the chipping machine. The most common concept of drive control in mobile chipping machines features two operational states. The first state is idle work, with rotation speed that enables maximum torque. The second state is caused by the material subjected to chipping, as a result of drive load change. The lack of electronic control (in the injection-ignition system) and sensors (recording the drive's parameters) results in problematic data recording concerning working states (e.g., rotary speed, torque, fuel consumption, the efficiency of combustion processes) in real operating conditions. Meanwhile, there are no publications on that topic. Such data analyses are performed mainly for working machinery such as excavators and loaders, with drives that are equipped with the EOBD (European On-Board Diagnostic) system [25-32].

We estimated the fuel consumption of wood chippers utilizing various control and fuel feed systems, as well as the different ratios of idle and under load operating time. Analysis of operating time was performed for the wood chipping process in relation to the distance between the chipper and the branch stack [33]. These studies showed that as a result of branch delivery performed by one operator over the distance of $0.5 \mathrm{~m}$, the idle work time was equal to $22 \%$ and was growing as the distance between the branch stack and the chipper increased. Systems that limit the fuel consumption of working internal combustion engines depend on operating conditions, e.g., start-stop systems in vehicles, are considered as beneficial and effective even when they are used $20 \%$ of the time [34]. This is the premise for the development of a new, innovative system that reduces fuel consumption and quantitative exhaust gas emissions by adapting the drive rotational speed to current operating conditions.

The concept of such a system in machinery intended for forestry is a maintenance-free and adaptive control system of a wood chipper drive with low-power spark-ignition engines [22]. Such a system has two idle working states. In the first state (1), high rotational speed allows for reaching either maximum power or maximum torque (like in the classic control method). The second (2) idle working state enables automatic reduction of engine rotational speed given that the internal combustion number of cycles is reduced. As a result, this leads to both decreased fuel consumption and quantitative exhaust gas emissions. The respective working states are activated maintenance-free via optical sensors located in the feed channel. The sensor used in the discussed solution is triggered by the detection of objects in the feed channel. When this happens, the rotational speed of the idling engine increases (the first state (1) is activated). After the chipping process is complete, the rotational speed is reduced to low (the second (2) state is activated). This concept does not affect the operating parameters of the drive unit during the chipping process (the third state (3)). 
This paper presents the results of fuel consumption tests of a cylindrical chipper driven by a low-power spark-ignition internal combustion engine with three different configurations. The first configuration (A) is an engine with a carburetor fuel feed system utilizing the classic control concept. The second (B) is an engine with an injection system that uses the classic control concept. The third (C) is an engine with an injection system fitted with an adaptive control system. Throughout the research, various active and idling operation times were considered. The purpose of this paper is to measure and demonstrate the differences in fuel consumption depending on the system's design and the adopted idea of chipper drive control.

\section{Materials and Methods}

For the experimental research, a chipper was used which, after initial stage testing, was modernized in terms of design and drive unit control. Tests were carried out in two stages. During the first stage, it was carried out in set exploitation conditions:

- Idling at low speed (1).

- Idling with maximum torque (2).

- Operation through a continuous chipping process (3).

During the second stage of research, the cylindrical wood chipper was tested in periodicallyvariable exploitation conditions (4). In this research, the load of the chipper's drive varied periodically, as such the situation imitated the frequency of branch being supplied to the chipper. The results of periodically-variable supply of branches were presented as the percentage contribution of time in the chosen exploitation state. The research was carried out considering three distances between piles of branches and the chipper (resulting from the previously published research [33]. This reflected the percentage contribution of idle to chipping work time. Percentage contribution of idle to chipping work time during experiments was defined per Table 1 . The research was carried out in ten repetitions for every exploitation conditions and fuel supply systems. One test took about an hour.

Table 1. Percentage of operating conditions times depending on the distance between the branch stack and the chipper.

\begin{tabular}{cc}
\hline $\begin{array}{c}\text { Distance between the Pile of Branches } \\
\text { and the Chipper }\end{array}$ & $\begin{array}{c}\text { Percentage of Time for the Different Operating } \\
\text { States Chipping/Idle Work }\end{array}$ \\
\hline $0.5 \mathrm{~m}$ & $78 \% / 22 \%$ \\
$1.5 \mathrm{~m}$ & $71 \% / 29 \%$ \\
$2.5 \mathrm{~m}$ & $65 \% / 35 \%$ \\
\hline
\end{tabular}

The subject of the performed research was a Red Dragon RS-100 wood chipper driven by a German GX 390 OHV four-stroke spark-ignition engine (Figure 1a). The factory configuration version (A) uses a carburetor fuel feed system and a contactless ignition system with a fixed ignition angle [35]. It is intended for processing wood waste and branches with a diameter of up to $80 \mathrm{~mm}$. Then, the original design (A) was modernized to the second version (B). It was developed through the application of an electronic injection-ignition system developed by the authors [36].

The basic component of the developed system was the ECU EMU MASTER central control unit which enabled the processes of the injection and ignition system control to be programmed. This system also provides monitoring and recording capabilities and allows indirect injection of fuel to the intake duct before throttle. Examination of this version (B) was conducted in the second stage of research before it was modernized by retrofitting a proprietary system of rotational speed control. Thus, the functioning of the machine became dependent on exploitation conditions, which resulted in the third version of the wood chipper (C).

The essence of the used rotational speed control system was the utilization of signals from optical sensors (placed in the feed channel) that control the two idling work states of the machine. These 
signals use an algorithm that controls the rotational speed of the drive by changing the position of the electronic air throttle. This version of wood chipper was tested in the third stage of the research. A schematic of the innovative injection-ignition system used in the Ger man GX390 engine, together with the maintenance-free detection and adaptive chipper drive control system is shown in Figure 2. The developed prototype is presented in Figure $1 \mathrm{~b}-\mathrm{d}$.
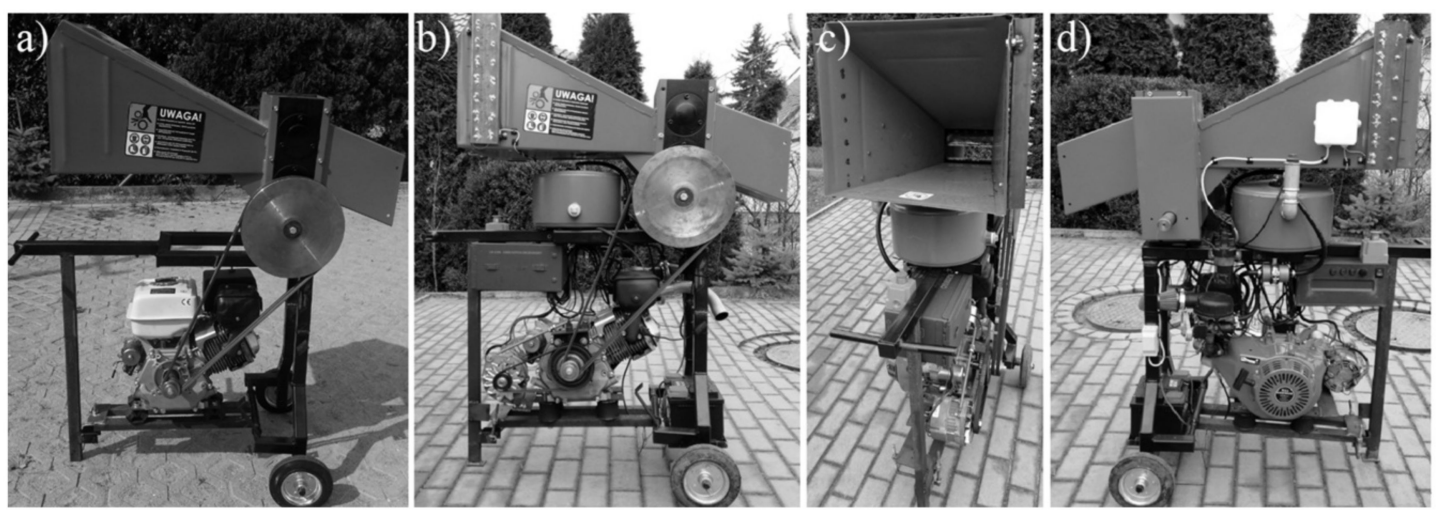

Figure 1. Red Dragon RS-100 type cylindrical chipper: (a) with a German GX 390 type engine; (b-d) with the adaptive control system.
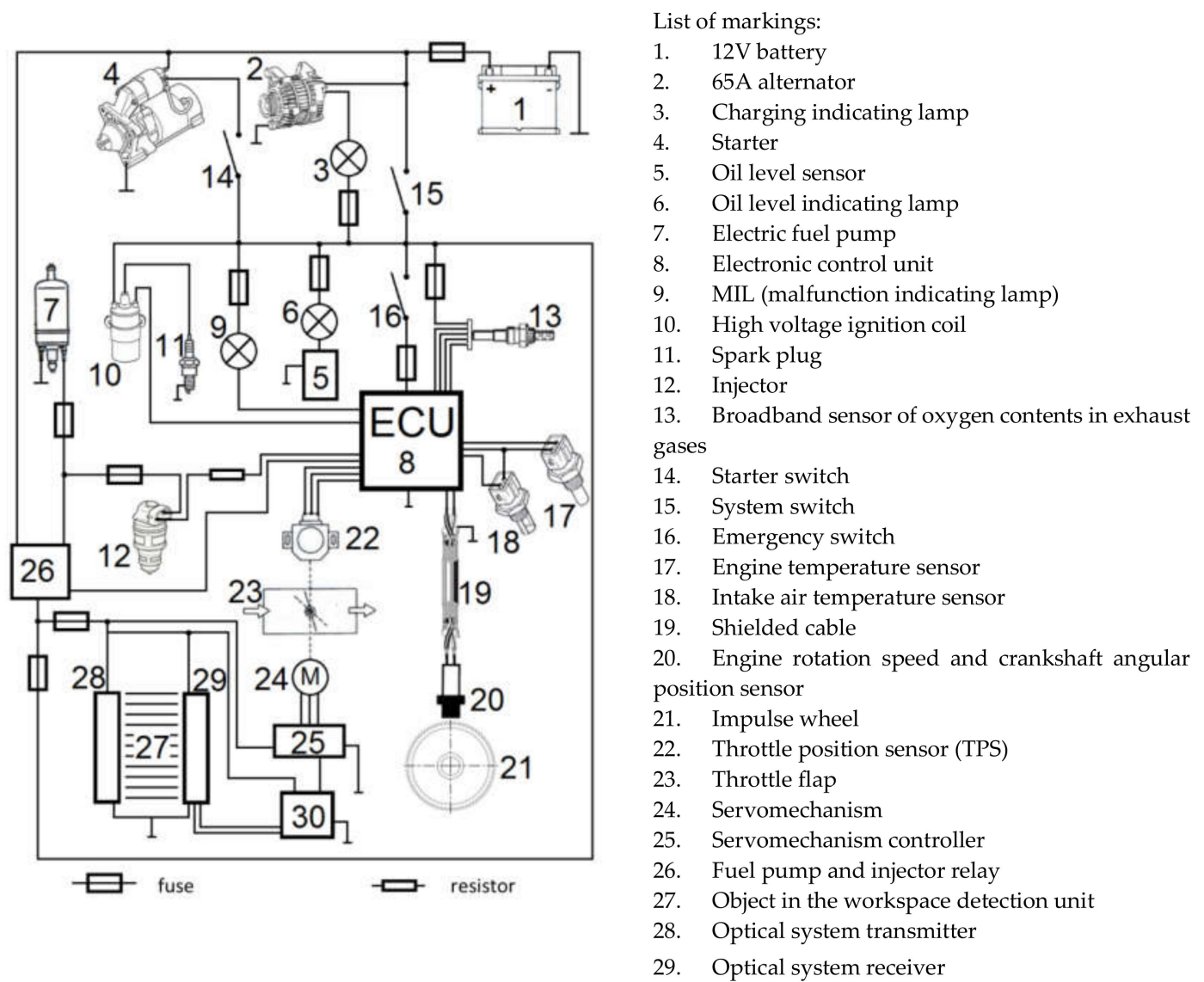

Figure 2. Schematic of the innovative injection-ignition system used in the German GX390 with a maintenance-free detection and adaptive chipper drive control system.

Research on the machine operating parameters, fuel consumption, and operating conditions was carried out on the same chipper with various drive system configurations (A, B, C). The tests were carried out on a cylindrical chipper with an internal combustion engine with three different fuel supply systems: 
- The first system-equipped with a carburetor fuel feed system and the classic control concept (A).

- The second system-equipped with an electronic injection system and the classic control concept (B).

- The third system-equipped with an electronic injection system after reequipping with a maintenance-free and adaptive rotation speed control system (C).

Freshly cut Walnut branches (Juglans regia) with a diameter in the biggest cross-section at approximately $80 \mathrm{~mm}$ and humidity of $30 \%$ were chipped at every stage of the tests. The trees came from areas that were prepared for building plots, and their branches were pruned irregularly. The specimens that underwent the tests were a representative of medium hardwood species following Janka classification [37]. The Janka hardness test measures the resistance of a sample of wood to denting and wear. It measures the force required to embed an 11.28 millimeters ( 0.444 in) diameter steel ball halfway into a sample of wood $[38,39]$.

The statistical analysis consisted of performing the distribution normality test using the Shapiro-Wilk method, rejecting excessive errors using the Chauwenet method and determining the standard deviation for the mean of the measurements. For the measurement results, the mean value was calculated considering corrections according to the Student's $t$ distribution for the $95 \%$ confidence level (see Tables 2-6) [40-44].

The measurement of actual fuel consumption was modelled using the volumetric method $[45,46]$. The measurement included providing a specified amount of fuel to the measuring cylinder, performing work under predefined operating conditions, and then checking the level of fuel consumption, which yielded an accuracy of $0.002 \mathrm{~L}$.

\section{Results}

Fuel consumption test results of a cylindrical chipper driven by an internal combustion engine with a carburetor fuel supply system (A) from the first stage are presented in Table 2. The results for the fuel injection system (B) are shown in Table 3.

Table 2. Results of fuel consumption measurements of a cylindrical chipper powered by an internal combustion engine with a carburetor fuel supply system (A); AVG-arithmetic average, SD-standard deviation of the mean, I-incertitude limits using the Student's t distribution for a 95\% confidence level.

\begin{tabular}{|c|c|c|c|}
\hline \multicolumn{4}{|c|}{ Operating Conditions } \\
\hline \multirow{2}{*}{ Test No. } & $\begin{array}{l}\text { Idle Work with Low } \\
\text { Rotational Speed (1) }\end{array}$ & $\begin{array}{l}\text { Idle Work with High Rotational } \\
\text { Speed (High Torque) (2) }\end{array}$ & $\begin{array}{l}\text { Continuous } \\
\text { Chipping (3) }\end{array}$ \\
\hline & \multicolumn{3}{|c|}{ Average Fuel Consumption $\left[1 \mathrm{~h}^{-1}\right]$} \\
\hline AVG & 0.602 & 1.203 & 3.041 \\
\hline $\mathrm{SD}$ & 0.0054 & 0.0056 & 0.1214 \\
\hline I & 0.0120 & 0.0124 & 0.2704 \\
\hline
\end{tabular}

Table 3. Results of fuel consumption measurements of a cylindrical chipper powered by an internal combustion engine with an injection fuel supply system (B); AVG-arithmetic average, SD-standard deviation of the mean, I-incertitude limits using the Student's t distribution for a 95\% confidence level.

\begin{tabular}{cccc}
\hline \multirow{3}{*}{ Test No. } & \multicolumn{3}{c}{ Operating Conditions } \\
& $\begin{array}{c}\text { Idle Work with Low } \\
\text { Rotational Speed (1) }\end{array}$ & $\begin{array}{c}\text { Idle Work with High Rotational } \\
\text { Speed (High Torque) (2) }\end{array}$ & $\begin{array}{c}\text { Continuous } \\
\text { Chipping (3) }\end{array}$ \\
\cline { 2 - 4 } & \multicolumn{3}{c}{ Average fuel consumption $\left[\mathbf{~ h}^{\mathbf{- 1}}\right]$} \\
\hline AVG & 0.374 & 1.310 & 1.185 \\
SD & 0.0073 & 0.0063 & 0.0265 \\
I & 0.0162 & 0.0140 & 0.0590 \\
\hline
\end{tabular}

The fuel consumption for the cylindrical wood chipper with a carburetor fuel supply system (A) during idle work with low rotational speed (1) was $0.602 \pm 0.00541 \mathrm{~h}^{-1}$. The consumption was 
twice as high during idle work with a high rotational speed (2). While continuous chipping (3), fuel consumption varies depending on the type of material being processed. Despite the same initial cross-section for all tested branches, fuel consumption differed as a result of the different number of shoots on branches. Fuel consumption in these conditions was several times greater than during idle work.

Fuel consumption for the cylindrical wood chipper with an injector fuel supply system (B) during idle work with a low rotational speed (1) was $0.374 \pm 0.00731 \mathrm{~h}^{-1}$. The consumption became much higher when the device was idling with a high rotational speed (2). While continuous chipping (3), fuel consumption was lower in comparison to the idle work with a high rotational speed (2), but still is a few times higher than during idle work with a low rotational speed (1). These results could be explained based on the adopted concept of controlling and recognizing loads in the drive system of the machine.

The second stage of research could be characterized as real exploitation conditions due to the periodically-variable loads of the chipper (3). Obtained results concerning fuel consumption for the cylindrical wood chipper with the carburetor fuel system (A) are presented in Table 4 . The developed system in conditions ranging from $22 \%$ to $35 \%$ of idle work time was characterized by fuel consumption from $2.126 \pm 0.0670 \mathrm{l} \cdot \mathrm{h}^{-1}$ to $1.998 \pm 0.0513 \mathrm{l} \cdot \mathrm{h}^{-1}$. A $13 \%$ increase in idle work time resulted in a $6 \%$ reduction in fuel consumption. Therefore, this proved that the examined system was characterized by the decrease in fuel consumption with the increase of idle work time. Rest of the recorded data is presented in Tables 5 and 6 for the wood chipper with an injector fuel supply system (B) and the wood chipper with an adaptative control system for fuel injector system (C), respectively. The system (B) in conditions ranging from $22 \%$ to $35 \%$ of the idle work time was characterized by fuel consumption from $1.252 \pm 0.0117 \mathrm{l} \cdot \mathrm{h}^{-1}$ to $1.279 \pm 0.0115 \mathrm{l} \cdot \mathrm{h}^{-1}$. A $13 \%$ increase in idle operation time resulted in a $2.2 \%$ increase in fuel consumption. This result showed that the tested system, along with the increase in idle time, was characterized by an increase in fuel consumption. However, this consumption was lower than for the system (A). System (C), as assumed, was the most susceptible to changes in idle/load work time ratio in conditions ranging from $22 \%$ to $35 \%$ of idle work time. It was characterized by fuel consumption from $0.951 \pm 0.0509 \mathrm{l} \cdot \mathrm{h}^{-1}$ to $0.515 \pm 0.04321 \mathrm{l} \cdot \mathrm{h}^{-1}$. A $13 \%$ increase in idle work time reduced fuel consumption by approximately $45.9 \%$. This result indicated that the adaptive system (C) showed the highest drop in fuel consumption under the presented conditions.

The values of the standard deviation indicated that the system (B) was the least susceptible to changes in the amount of fuel consumption in the tested operating conditions and was on average \pm $0.0123 \mathrm{l} \cdot \mathrm{h}^{-1}$. System (A) was characterized by an increase in the average standard deviation of $357.7 \%$ and amounted to $\pm 0.05631 \cdot \mathrm{h}^{-1}$. For system (C), it increases by $286.2 \%$ and was equal to $0.047511 \cdot \mathrm{h}^{-1}$. On this basis, one can indicate the tendency of systems (A) and (C) to shift fuel consumption as a result of different work conditions. In system (A), the centrifugal mechanism reacted to load changes, while in system $(C)$, the device responded to change of the rotational speed need of the drive. This contrasted to system (B) which during the operation was not susceptible to any of the above regulations. A detailed analysis of the systems focused on their comparison is presented in the next chapter.

Table 4. The results of fuel consumption of the cylindrical wood chipper with carburetor fuel supply system (A) in periodically-variable exploitation conditions (3); AVG-arithmetic average, SD-standard deviation of the mean, I-incertitude limits using the Student's t distribution for a 95\% confidence level.

\begin{tabular}{|c|c|c|c|}
\hline \multicolumn{4}{|c|}{ Operating Conditions } \\
\hline \multirow{3}{*}{ Test No. } & \multicolumn{3}{|c|}{ Percentage of Time for the Different Operating States: Chipping/Idle Work } \\
\hline & $78 \% / 22 \%$ & $71 \% / 29 \%$ & $65 \% / 35 \%$ \\
\hline & \multicolumn{3}{|c|}{ Average Fuel Consumption $\left[1 \mathrm{~h}^{-1}\right]$} \\
\hline AVG & 2.126 & 2.053 & 1.998 \\
\hline SD & 0.0670 & 0.0506 & 0.0513 \\
\hline $\mathrm{I}$ & 0.1492 & 0.1128 & 0.1143 \\
\hline
\end{tabular}


Table 5. The results of fuel consumption of the cylindrical wood chipper with injector fuel supply system (B) in periodically-variable exploitation conditions (3); AVG-arithmetic average, SD-standard deviation of the mean, I-incertitude limits using the Student's t distribution for a $95 \%$ confidence level.

\begin{tabular}{|c|c|c|c|}
\hline \multicolumn{4}{|c|}{ Operating Conditions } \\
\hline \multirow{3}{*}{ Test No. } & \multicolumn{3}{|c|}{ Percentage of Time for Different Operating States: Chipping/Idle Work } \\
\hline & $78 \% / 22 \%$ & $71 \% / 29 \%$ & $65 \% / 35 \%$ \\
\hline & \multicolumn{3}{|c|}{ Average Fuel Consumption $\left[1 \mathrm{~h}^{-1}\right]$} \\
\hline AVG & 1.252 & 1.260 & 1.279 \\
\hline SD & 0.0117 & 0.0136 & 0.0115 \\
\hline I & 0.0261 & 0.0303 & 0.0255 \\
\hline
\end{tabular}

Table 6. The results of fuel consumption of the cylindrical wood chipper with an injector fuel supply system equipped with an adaptative drive control system in periodically-variable exploitation conditions. AVG-arithmetic average, SD-standard deviation of the mean, I-incertitude limits using the Student's t distribution for a 95\% confidence level.

\begin{tabular}{cccc}
\hline & \multicolumn{3}{c}{ Operating Conditions } \\
\hline \multirow{3}{*}{ Test No. } & \multicolumn{3}{c}{ Percentage of Time for the Different Operating States: Chipping/Idle Work } \\
\cline { 2 - 4 } & $\mathbf{7 8 \% / \mathbf { 2 2 } \%}$ & $\mathbf{7 1 \%} \mathbf{2 9} \%$ & $\mathbf{6 5 \%} \mathbf{3 5 \%}$ \\
\cline { 2 - 4 } & \multicolumn{3}{c}{ Average Fuel Consumption $\left[\mathbf{1 ~ h}^{\mathbf{- 1}}\right]$} \\
\hline AVG & 0.951 & 0.633 & 0.515 \\
SD & 0.0509 & 0.0484 & 0.0432 \\
I & 0.1135 & 0.1080 & 0.0962 \\
\hline
\end{tabular}

\section{Discussion}

The main assessed parameter was the energy consumption of work of chipping machines expressed by fuel consumption. The first stage research results enabled a comparison of fuel consumption in constant exploitation conditions. Selected test results are shown in Figure 3. The analysis of the fuel consumption in these three conditions allowed us to determine the range of fuel consumption that one can expect in periodically-variable exploitation conditions.

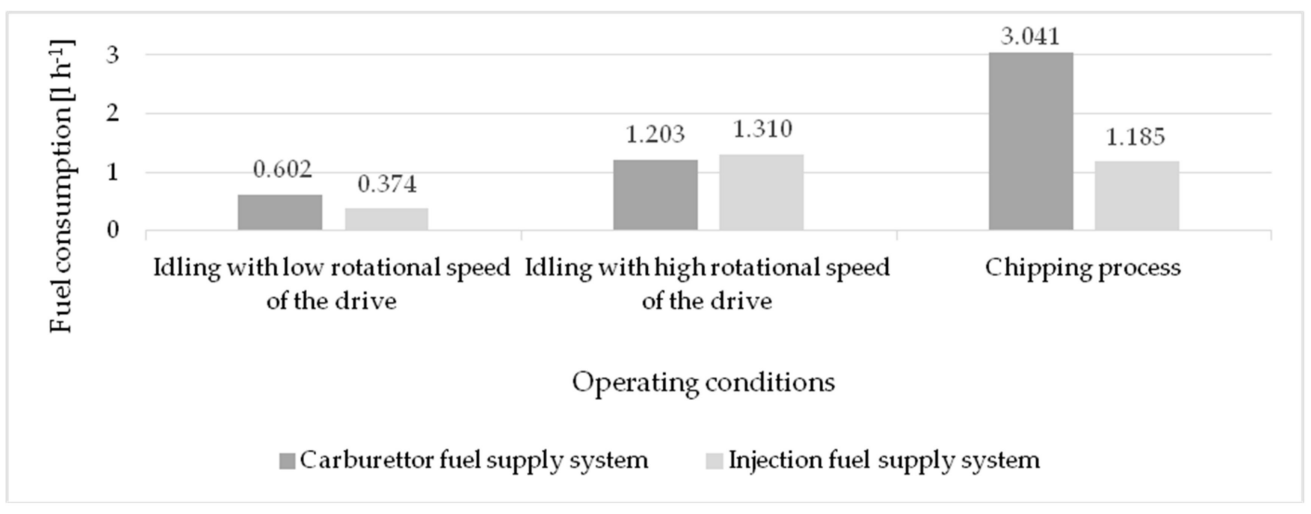

Figure 3. Fuel consumption in selected operating conditions: Idle work with high (1) and low (2) rotational speed, with a continuous chipping process (3).

Idle work at low rotational speed is more effective in the case of a system with electronic fuel injection (B). The operation at high rotational speed under the same load conditions is more advantageous in the case of a system with a carburetor fuel feed (A). The reason for this is the lower rotational speed during active work (while chipping, i.e., about $3800 \mathrm{rpm}$ ). The drive with the injection system (B) operates at $4200 \mathrm{rpm}$, where more combustion cycles occur. The differences in the rotational speed values were related to the different control concept, that resulted from the reference characteristics 
of the engine. In the carburetor system (A), a significant load on the working mechanism caused the rotational speed to decrease. This was limited by a change in throttle position that caused an increase in the fuel-air mixture inflow to the combustion chamber. The process provided a greater fuel-air mixture volume making it possible to increase rotational speed, thereby allowing maximum torque to be reached again. This action was carried out by a centrifugal regulator integrated with the carburetor. In the constant branches chipping process (3) this caused a significant load on the working mechanism. Because of this, fuel consumption differed significantly depending on the fuel supply system used.

In the injection system (B), the load value was recognized based on the signal from the throttle position sensor. Hence, the load caused by the object to be fragmented was not detected by the system. In the injection system, the current load value was known due to the signal from the throttle angle sensor. Therefore, the demand for increased torque (caused by appearing elements to be chipped) could not be considered by the injection system.

This reduces the rotational speed and the ability to achieve the maximum torque value. The system was designed in such a way that during idle operation it rotates at speeds greater than that required to achieve maximum torque. The appearance of the load results in a decrease in the rotational speed, and, in turn, it reaches a value guaranteeing the maximum torque to be obtained. This is in accordance with the actual operating characteristics of the internal combustion engine.

The combustion engine with the fuel injection system (A) used in the first stage tests ensured that the fuel-air mixture was maintained at a similar level during chipping. It was done by reducing the rotational speed (and the number of cycles) which led to lower fuel consumption.

As a result of applying an injection system (B), the fuel consumption during idle work with low rotational speed decreased at about $38 \%$. During idle work at high speed, the fuel consumption increased by $9 \%$. In the case of chipping objects that caused a significant load of the drive, the modification allowed the lowering of fuel consumption by $61 \%$ (Figure 3 ). The second stage fuel consumption test results allowed for a comparison of the fuel consumption in periodically-variable exploitation conditions (4) with different fuel supply systems (Figure 4). To compare systems in constant conditions, we supplied the branches in such a way that allowed us to keep a constant ratio between chipping and idle work. If the operating conditions were close to reality, the carburetor system with the classic control system showed a significantly higher (by 56-70\%) fuel consumption than the injection system. Another important factor affecting fuel consumption was the method of controlling the injection system. An adaptation of the system to operating conditions ensured a reduction of fuel consumption compared to classic control (with carburetor-A) by about:

- $24 \%$ with a chipping/idle work ratio of $78 \%$ to $22 \%$,

- $50 \%$ with a chipping/idle work ratio of $71 \%$ to $29 \%$,

- $60 \%$ with a chipping/idle work ratio of $65 \%$ to $35 \%$.

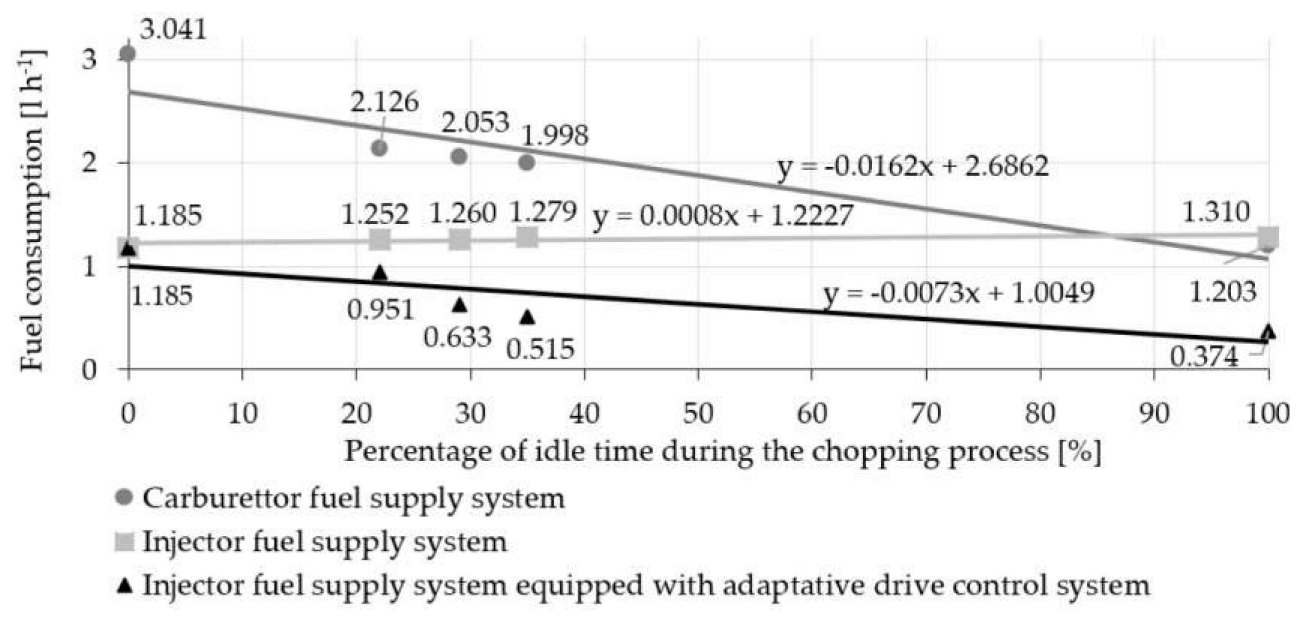

Figure 4. Fuel consumption under selected operating conditions: Transient exploitation conditions (4). 
Fuel consumption in the adaptive system was largely dependent on the ratio between chipping and idle work times. This value decreased with the increase of idle work during machine operation time in processing operations.

The above comparison of drive control systems and concepts shows that the average fuel consumption per hour (apart from the injection time) is affected by the rotational speed, on which the number of cycles of the internal combustion engine depends. The introduction of a system with the possibility of adaptation (in terms of mechanical power) to operating conditions will reduce fuel consumption.

A similar method of reducing emissions from the internal combustion engine was used in motor vehicles by introducing the start-stop system. It is estimated that using systems of this kind reduces fuel consumption and carbon dioxide emissions by $5-10 \%$, and in hybrid vehicles by $10-25 \%[47,48]$. Cieślik et al. [34] showed that the start-stop system is used for $20 \%$ of the time when the vehicle is operating in the urban environment. For chipping machines, the frequency of changes in operating states, and especially the length of idle work time is too short to enable turning the engine off. According to the authors, the rotational speed decreasing system is beneficial. In addition, system utilization time can be assumed to be $20 \%$ or more over the entire operation cycle time, according to the test results concerning real conditions for mobile chipping machines.

The quantitative reduction of exhaust gas emissions results from the decrease in fuel consumption, but the quality of exhaust gases is also important. The adaptive system is characterized by the extended work time in a transient state. Such a state is characterized by the lack of fuel-air mixture regulation in feedback, which may result in a different composition of exhaust gases than at the combustion of the stoichiometric fuel-air mixture, which is the most advantageous.

The last compared parameter of the described systems was the design and applied components. A broadband sensor of oxygen content in the exhaust gases and an electronically controlled throttle are the distinguishing elements of the systems used in the described research, in relation to other innovative drive designs of non-road mobile machines. The lack of a fuel vapor absorption system offered in other modules intended for motor modernization from this category (in means of mechanical power and mass) is a disadvantage here.

Factory motor equipment (the most common is the carburetor) can be characterized by its limited ability to adjust the composition of the fuel-air mixture and the probability of settings loss due to machine operation. The modernization of the injection-ignition system of the drive unit is characterized by a significant increase in the number of components used. Using the modernized system can be considered a disadvantage in term of costs, especially when compared to machines equipped with a classic drive unit. However, the increase in ecological requirements will lead to the development of such drive units, just like in the case of motor vehicles.

\section{Conclusions}

The application of low-power drive units with electronic fuel injection in wood chippers compared to drives with a carburetor system showed reduced fuel consumption from $36 \%$ to $41 \%$. This was dependent on the ratio of active and passive work time in the chipping process. Operation of the device with the possibility of adapting the drive control process to operating conditions by changing the rotational speed ensured a reduction of fuel consumption from $41 \%$ to $60 \%$. The adaptive drive control systems are beneficial in combustion engines. Still, in case of branch chipping machines, as it turns out, it is more beneficial to adjust rotational speed than to use the start-stop system as in cars. The advantage of combustion engines with adaptive drive control systems are:

- Automatically attaining two idling states by changing the rotational speed, which ensures a reduction in fuel consumption and quantitative exhaust gas emissions,

- Limitation of the operator's effort in terms of their intensity of attention,

- Reduction of the operator's stress related to the costs of machine operation. 
Operation of the device with the possibility of adapting the drive control process to operating conditions through adaptive rotation speed control ensures a reduction in fuel consumption. It reduces the quantity of exhaust gas emissions. Qualitative assessment of the generated exhaust gases requires further testing, e.g., in real operating conditions using PEMS (the Portable Emissions Measurement System). Another beneficial effect of the introduced system discussed here is the limitation of the operator's functions in terms of rotational speed regulation depending on operational needs. After starting the motor, the operator does not interfere in the control process (focusing their attention on the supply of raw material for processing), and the control function is activated automatically. In the future, this type of system should be used in machines driven by combustion engines with periodically-variable work cycles, used in forestry.

Further work can be focused on determining the chipping to idle work time ratio for which the use of this system ceases to be profitable. Moreover, after performing qualitative tests of the exhaust emissions, it can be expected that further work on the adaptive system should be conducted. It should be in the direction of controlling combustion processes of internal combustion engines in the field of rotational speed changes (for transient work states).

\section{Patents}

The design solution described in this paper is subject to a patent application in Poland: $Ł$. Warguła, P. Krawiec, K.J. Waluś, 2017a: The system and method of speed control of wood chipper drives (original text in Polish: Układ i sposób sterowania prędkością obrotową napędu rębaka do drewna), Poznan University of Technology, Poznań, Poland, application number: P.423369, date of filing 06.11.2017.

In addition, the design developed on the basis of the above-mentioned patent application was rewarded with a silver medal at the XII International Invention and Innovation Show INTARG, 4-5.06.2019, Katowice, Poland, and a silver medal at the International Warsaw Invention Show IWIS 14-16.10.2019, Warsaw, Poland.

Author Contributions: Conceptualization, Ł.W. and K.J.W.; methodology, Ł.W. and P.K.; software, Ł.W.; validation, Ł.W., K.M. and P.K.; formal analysis, Ł.W. and K.J.W.; investigation, Ł.W. and P.K.; resources, Ł.W. and K.J.W.; data curation, Ł.W. and M.K.; writing-original draft preparation, Ł.W., K.W and M.K.; writing-review and editing, M.K., P.K. and Ł.W.; visualization, Ł.W. and P.K.; supervision, Ł.W.; project administration, Ł.W.; funding acquisition, P.K. All authors have read and agreed to the published version of the manuscript.

Funding: Research was performed as part of the project “Interdisciplinary Dean's Grant (IDG) of Poznań University of Technology" determined in the subject for the 2020 year-air quality in Poznan and how to improve it. Project title: "Design and research of mobile machines shredding wastes from urban agriculture processes for innovative construction solutions limiting the impact on the natural environment and machine operators" (33/32/SIGR/3334) financed by the Poznan University of Technology.

Conflicts of Interest: The authors declare no conflict of interest.

\section{References}

1. Haavikko, H.; Kärhä, K.; Hourula, M.; Palander, T. Attitudes of Small and Medium-Sized Enterprises towards Energy Efficiency in Wood Procurement: A Case Study of Stora Enso in Finland. Croat. J. For. Eng. 2019, 40, 107-123.

2. Gałęzia, T. Energy balance and time-consumption of selected components in technological chain of forest biomass harvesting. Sylwan 2013, 157, 419-424.

3. Calcante, A.; Facchinetti, D.; Pessina, D. Analysis of Hazardous Emissions of Hand-Operated Forestry Machines Fuelled with Standard Mix or Alkylate Gasoline. Croat. J. For. Eng. 2018, 39, 109-116.

4. Acuna, M. Timber and biomass transport optimization: A review of planning issues, solution techniques and decision support tools. Croat. J. For. Eng. 2017, 38, 279-290.

5. Mihelič, M.; Spinelli, R.; Poje, A. Production of Wood Chips from Logging Residue under Space-Constrained Conditions. Croat. J. For. Eng. 2018, 39, 223-232. 
6. Strandgard, M.; Mitchell, R.; Wiedemann, J. Comparison of Productivity, Cost and Chip Quality of Four Balanced Harvest Systems Operating in a Eucalyptus globulus Plantation in Western Australia. Croat. J. For. Eng. 2019, 40, 39-48.

7. Spinelli, R.; de Arruda Moura, A.C. Productivity and Utilization Benchmarks for Chain Flail Delimber-Debarkers-Chippers Used in Fast-Growing Plantations. Croat. J. For. Eng. 2019, 40, 65-80.

8. Macko, M.; Tyszczuk, K.; Śmigielski, G.; Mroziński, A. Utility of an unitary-shredding method to evaluate the conditions and selection of constructional features during grinding. In Proceedings of the MATEC Web of Conferences, Proceedings of the Machine Modelling and Simulations, Sklené Teplice, Slovak Republic, 5-8 September 2017; EDP Sciences: Lez Ili, France, 2018; Volume 157.

9. Guerrini, L.; Tirinnanzi, A.; Guasconi, F.; Fagarazzi, C.; Baldi, F.; Masella, P.; Parenti, A. A Plackett-Burman Design to Optimize Wood Chipper Settings. Croat. J. For. Eng. 2019, 40, 81-87.

10. Spinelli, R.; Magagnotti, N.; Schweier, J. Trends and perspectives in coppice harvesting. Croat. J. For. Eng. 2017, 38, 219-230.

11. Baldauf, R.; Fortune, C.; Weinstein, J.; Wheeler, M.; Blanchard, F. Air contaminant exposures during the operation of lawn and garden equipment. J. Expo. Sci. Environ. Epidemiol. 2006, 16, 362-370. [CrossRef]

12. Czerwiński, J.; Kurzwart, M.; Mayer, A.; Comte, P. Particle Emissions of Modern Handheld Machines; SAE Techn Paper; SAE: Warrendale, PA, USA, 2014.

13. Merkisz, J.; Lijewski, P.; Pielecha, J. PEMS-based investigations into exhaust emissions from non-road and rail vehicles. Comb. Eng. 2016, 166, 46-53.

14. Liu, S.; Han, W.; Zeng, J.; Wang, J. Analysis of combustion and emission characteristics of electronic controlled low pressure injected small gasoline engine. Trans. Chin. Soc. Agric. Eng. 2016, 32, 92-97.

15. Dimou, V.; Anezakis, V.; Demertzis, K.; Iliadis, L.S. Comparative analysis of exhaust emissions caused by chainsaws with soft computing and statistical approaches. Int. J. Environ. Scie. Technol. 2017, 3-1. [CrossRef]

16. Lijewski, P.; Fuć, P.; Dobrzyński, M.; Markiewicz, F. Exhaust emissions from small engines in handheld devices. In Proceedings of the MATEC Web of Conferences, VII International Congress on Combustion Engines, Poznań, Poland, 27-29 June 2017; EDP Sciences: Lez Ili, France, 2017; Volume 118.

17. Hooper, B.; Parker, R.; Todoroki, C. Exploring chainsaw operator occupational exposure to carbon monoxide in forestry. J. Occup. Environ. Hyg. 2017, 14, D1-D12. [CrossRef]

18. Waluś, K.J.; Warguła, Ł.; Krawiec, P.; Adamiec, J.M. Legal regulations of restrictions of air pollution made by non-road mobile machinery-the case study for Europe: A review. Environ. Sci. Pollut. Res. 2018, 25, 3243-3259. [CrossRef] [PubMed]

19. Warguła, Ł.; Waluś, K.J.; Krawiec, P.; Polasik, J. Electronic control injection-ignition systems in propulsion of non-road mobile machinery. J. Mech. Trans. Eng. 2018, 70, 61-78.

20. Warguła, Ł.; Waluś, K.J.; Krawiec, P. Small engines spark ignited (SI) for non-road mobile machinery-review. In Proceedings of the Transport Means 2018: 22nd International Scientific Conference, Trakai, Lithuania, 3-5 October 2018; Kaunas University of Technology: Trakai, Lithuania, 2018; Part 2, pp. 585-591.

21. Szpica, D.; Czaban, J. Operational assessment of selected gasoline and LPG vapour injector dosage regularity. Mechanika 2014, 20, 480-489. [CrossRef]

22. Warguła, Ł.; Krawiec, P.; Waluś, K.J. The System and Method of Speed Control of Wood Chipper Drive; original title in Polish: Układ i sposób sterowania prędkością obrotową napędu rębaka do drewna; Poznan University of Technology: Poznań, Poland, 2017; p. 423369.

23. Warguła, Ł.; Wojtkowiak, D.; Waluś, K.J.; Krawiec, P.; Wieczorek, B. The analysis of the efficiency of the control system of Wood chipper's driver with spark-ignition engine based on Skoda combustion engine 1.4 59kW. In Proceedings of the Transport Means 2017: 21st International Scientific Conference, Juodkrante, Lithuania, 20-22 September 2017; Part 2. Kaunas University of Technology: Juodkrante, Lithuania, 2017; pp. 452-458.

24. Regulation (EU). On Requirements for Emission Limit Values of Gaseous and Particulate Pollutants and Type-approval with Respect to Internal Combustion Engines for Mobile Machines Non-road, Amending Regulations (EU) No 1024/2012 and (EU) No 167/2013 and Amending and Repealing Directive 97/68/WE. No 2016/1628 of the European Parliament and of the Council of 14 September 2016. Off. J. Eur. Union 2016, L252, 53-117.

25. Merkisz, J.; Lijewski, P.; Fuć, P.; Weymann, S. Exhaust emission tests from non-road vehicles conducted with the use of PEMS analyzers. Maint. Reliab. 2013, 15, 364-368. 
26. Lijewski, P.; Merkisz, J.; Fuć, P. The analysis of the operating conditions of farm machinery engines in regard to exhaust emissions legislation. Appl. Eng. Agric. 2013, 29, 445-452.

27. Lijewski, P.; Merkisz, J.; Fuć, P. Research of exhaust emissions from a harvester diesel engine with the use of portable emission measurement system. Croat. J. For. Eng. 2013, 34, 113-122.

28. Lijewski, P.; Merkisz, J.; Fuć, P.; Daszkiewicz, P. The Comparison of the Exhaust Emissions from an Agricultural Tractor and a Truck. Appl. Mech. Mater. 2013, 391, 196-201. [CrossRef]

29. Lijewski, P.; Merkisz, J.; Fuć, P.; Siedlecki, M.; Ziółkowski, A. SAE Techn Paper; SAE: Warrendale, PA, USA, 2015.

30. Lijewski, P.; Merkisz, J.; Fuć, P.; Ziółkowski, A.; Rymaniak, Ł.; Kusiak, W. Fuel consumption and exhaust emissions in the process of mechanized timber extraction and transport. Eur J For Res. 2017, 136, 153-160. [CrossRef]

31. Fuć, P.; Lijewski, P.; Ziółkowski, A. Analysis of the $\mathrm{CO}_{2}, \mathrm{NOx}$ emission and fuel consumption from a heavy-duty vehicle designed for carriage of timber. IOP Conf. Ser. Mater. Sci. Eng. 2016, 148, 012065. [CrossRef]

32. Szymlet, N.; Lijewski, P.; Fuć, P.; Sokolnicka, B.; Siedlecki, M. Comparative analysis of passenger car and non-road machinery specific emission in real operating conditions. In Proceedings of the 2018 International Interdisciplinary PhD Workshop (IIPhDW), Swinoujście, Poland, 9-12 May 2018; pp. 226-230.

33. Warguła, Ł.; Waluś, J.K.; Krawiec, P. Determination of working conditions of mobile chipping wood machines in the aspect of innovative drive control systems. Sylwan 2019, 163, 765-772. [CrossRef]

34. Cieślik, W.; Pielecha, I.; Borowski, P. Effects of start-stop system on the operations of driver system Urban traffic conditions. J. Mech. Trans. Eng. 2015, 67, 15-26.

35. Warguła, Ł.; Waluś, K.J.; Krawiec, P.; Kukla, M. Research of the ignition advance angle characteristics on the example of a German GX 390 combustion engine. Autobusy Tech. Eksploat. Syst. Transp. 2017, 12, 1387-1391.

36. Warguła, Ł. Innovative injection-ignition system in a non-road small engine-construction system. In Proceedings of the Transport Means 2019: 23rd International Scientific Conference, Palanga, Lithuania, 2-4 October 2019; Part 2. Kaunas University of Technology: Palanga, Lithuania, 2019; pp. 931-935.

37. Warguła, Ł.; Kaczmarzyk, P.; Dziechciarz, A. The assessment of fire risk of non-road mobile wood chopping machines. J. Res. Appl. Agric. Eng. 2019, 64, 58-64.

38. Bektas, I.; Alma, M.H.; As, N. Determination of the relationships between Brinell and Janka hardness of eastern beech (Fagus orientalis Lipsky). For. Prod. J. 2001, 51, 84.

39. Green, D.W.; Begel, M.; Nelson, W. Janka Hardness Using Nonstandard Specimens; US Dept. of Agriculture, Forest Service, Forest Product Laboratory: Washington, DC, USA, 2006; p. 303.

40. ISO; IEC; OIML. Guide to the Expression of Uncertainty in Measurement; ISO; IEC; OIML: Geneva, Switzerland, 1995; Volume 122, p. 137.

41. International Organization for Standardization. International Vocabulary of Basic and General Terms in Metrology; ISO: Geneva, Switzerland, 1993.

42. International Standard ISO 3534-1: (1993) (E/F) Statistics_-Vocabulary and Symbols; ISO: Geneva, Switzerland, 1993.

43. International Organization for Standarization. International Vocabulary of Basic and General Terms in Metrology, 2nd ed.; International Organization for Standarization: Geneva, Switzerland, 1993.

44. Kendall, M.G.; Stuart, A. The Advanced Theory of Statistic; Charles Griffin \& Company Limited: London, UK, 1966.

45. Rychlik, A. Commercial vehicles fuel consumption measurement methods. Maint. Reliab. 2006, 4, 37-41.

46. Serdecki, W. Testing of Internal Combustion Engines; Poznan University of Technology: Poznań, Poland, 2012; ISBN 978-83-7775-105-3.

47. Setlak, R.; Fice, M. Start\&Stop system in Mild Hybrid drive and it's influence to fuel reduction in NEDC tests. Zeszyty Problemowe Politechniki Ślaskiej, Maszyny Elektryczne 2011, 90, 151-156.

48. Green Car Congress. Pike Research Forecasts Global Stop-start Vehicle Sales to Reach 37M Units Annually by 2020; 2011, 16:1 ratio over HEVs. Available online: www.greencarcongress.com/2011/06/ssv-20110601.html (accessed on 2 October 2018). 